TITLE:

A Neutral Proteinase of Monkey Liver
Microsomes: Solubilization, Partial
Purification and Properties(Abstract_要旨)

AUTHOR(S):

Sogawa, Kazuhiro

CITATION:

Sogawa, Kazuhiro. A Neutral Proteinase of Monkey Liver Microsomes : Solubilization, Partial Purification and Properties. 京都大学, 1979, 理学博士

ISSUE DATE:

1979-03-23

URL:

http://hdl.handle.net/2433/222160

RIGHT: 


\section{【59 】}

氏

名学 忍和博

学位の種類理学博士

学位記番号理 博 第 565 号

学位授与の日付昭和 54 年 3 月 23 日

学位授与の要件

学位規則第 5 条第 1 項該当

研究科・專攻

理学研究科動物学專攻

学位論文題目

A Neutral Proteinase of Monkey Liver MicrosomesSolubilization, Partial Purification and Properties

（サル肝臓ミクロソームの中性プロテイナーゼ——その可溶化，部 分精製执よび性質）

論文調查委員教授高橋健治 教授大沢済教授日高敏隆

\section{論文内容 の 要旨}

細胞内には各種プロテイナーゼが存在し，細胞内蛋白質の代謝分解や前駆体㔻白質の限定分解など多く の生理的に重要な役割を果たしていると考学られている。これらのプロテイナーゼの生理的役割を解明す るためには，それらの細胞内存在様式を明らかにするとともに，その分別，精製を行ない，その諸性状を 解明する必要がある。現在までのところ，この分野の研究はリソゾーム中のカテプシン系プロテイナーゼ についてある程度進んでいる以外極めて遅れている。本論文は, 本申請者が先に初めてその存在を見出し た，ミクロソーム膜結合中性プロテイナーゼについて，ニホンザル肝臓を用い，その可溶化条件を検討し て，膜系に和ける存在様式を探ぐるとともに，部分精製を行ない，その性状を検索したものである。

まずサル肝臟ミクロソーム膜系に強く結合し，凍解融解と $1 \mathrm{M} \mathrm{KCl}$ 処理では可溶化されない中性ェン ドプロティナーゼの存在を証明し, 多種の試薬を用いて, との可溶化を試みた。この結果, この酵素はデ オキシコール酸, コール酸, Triton X-114, Triton X-100, Emulgen 810 等の界面活性剂ではかなりよ く可溶化されるが, 種々のカオトロピックアニオン, 尿素, 塩酸グアニジン等では可溶化されないことが 判明した。これらの事実から，本酵素は表在性酵素ではなく，膜と強い蹯水性相互作用により結合してい る内在性酵素であると推定された。またデオキシコール酸、コール酸和よび Triton X-100を用いて可 溶化に対する可溶化剂との処理時間，可溶化剂濃度和よびミクロソーム膜蛋白濃度の影響等を検討し，可 溶化と精製に有効な条件を明らかにした。

さらに，これらの知見に基づき， $1 \mathrm{M} \mathrm{KCl}$ 抢よび $0.05 \%$ ドデシル硫酸ナトリウム処理したミクロソー ム膜より $1 \%$ Triton X-100 で本䣼素を可溶化した後，ハイドロキシルアパタイトクロマトグラフィー 执よびセファロース CL-6 B によるダル沪過法を用いて本酵素を部分精製した。この標品について，分子 量が約 88,000 であり, カゼインに対する最適 $\mathrm{pH}$ は 8.0 であること, ジイソプロピルフルオロリン酸, フェニルメタンスルホニルフルオリドで強く阻害されることから，活性部位に反応性セりン残基を有する セリンプロテイナーゼの一種であること，キモスタチンや金属キレート率（EDTA 特よび EGTA）でも 
かなり阻害されることから, キモトリプシンに若干類似性があり, 活性発現に金属イオンが何等かの関与 をすることなどが示された。また，尿素変性蛋白質に対する作用を検索し，ヒストンを最もよく水解し，

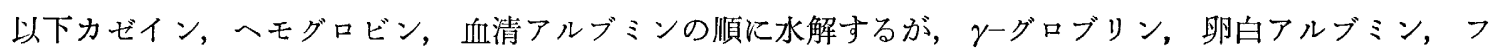
ィブリノーゲンには汪とんど作用しないことが示された。

以上の結果から，本酵素がミクロソーム膜の内在性蛋白質として，特異な生理的役割（膜蛋白質の代謝 回転あるいは分泌蛋白質の限定分解など）を果たしている可能性が推定された。

参考論文 4 篇は，サル肝蔵に抢ける本酵素の発見と，ネズミ肝臓に和ける同種酵素のミクロソーム局在 性の証明，ならびにサルの各種組織に㧍ける酸性プロテイナーゼの分布特性の検索と新しい螢光標識基質 を用いるプロテイナーゼ活性測定法に関するものである。

\section{論文審 査の結 果の要旨}

細胞内プロテイナーゼの生理的役割の重要性が最近注目されて来ているが，これらのプロテイナーゼに 関する研究は従来大変遅れて㧍り，その精製や性状の解明が強く望まれている。特に，細胞内オルガネラ の膜系と強く結合しているタイプのプロテイナーゼはオルガネラの生理的機能とも関連して重要と考兄ら れるが，この種のプロテイナーゼに関する知見は注とんど皆無である。申請者は，先にラット肝臓中にミ クロソーム膜と強く結合するエンド型中性プロテイナーゼを初めて発見した。本研究ではサル肝臓を用い て同種酵素の膜系に和ける存在様式を詳細に追究するとともに，その部分精製を行ない，部分精製標品に ついて分子的，酵素的諸性状を明らかにしている。

申請者はまず，サル肝臓ミクロソーム分画について多数種の試剂を用いて本酵素の可溶化条件と可溶化 度を詳細に比較検索し，デオキシコール酸，コール酸，Triton X-100など限られた界面活性剤のみでよ く可溶化される事実から，本酵素が膜の表在性蛋白として膜成分と疎水性結合で強く結合していることを 結論した。したがって，本酵素は細胞内オルガネラの内在性エンド型中性プロテイナーゼとして初めて位 置づけられたわけであり，その学問的意義は大きい。

申請者はさらに，本酵素の精製条件を精力的に検討し，その部分精製に成功した。本酵素は存在量が極 めて微量でめる上に，特定の限られた種類の界面活性剂の存在下でのみ精製が可能でめるため，その精製 は極めて困難である。部分精製の段階ではあるが，精製にともならいくつかの難問題を解決し，他の同様 な酵素の精製にも適用しらる種々の知見を得た点で高く評価される。ぬた，部分精製酵素について，分子 量, 最適 $\mathrm{pH}$ ，各種阻害剤の影響，基質特異性等を詳細に検索し，本酵素が新しいタイプのエンド型中性 セリンプロテイナーゼであることを示した点も新知見として高く評価される。

以上，本論文はサル肝臓ミクロソーム膜に強く結合して存在するエンド型中性プロテイナーゼの存在を 証明し，その存在様式を詳細に検索するとともに，その部分精製法を確立し，諸性状を解明した初めての ユニークな論文であり，オルガネラの膜結合性プロテイナーゼの生理的役割解明への新しい研究の発展の 基礎となりらるものとして，その学問的貢献度は極めて高いものと考えられる。

よって，本論文は理学博士の学位論文として価値あるものと認められる。 